\title{
ARTICLE
}

\section{Mortality of early life stages of European pilchard Sardina pilchardus along the Atlantic Coast of Northwest Africa $\left(22^{\circ} 30 ’ \mathrm{~N}-26^{\circ} \mathrm{N}\right)$}

\author{
Mortalidad en los primeros estadios de desarrollo de la sardina europea \\ Sardina pilchardus a lo largo de la Costa Atlántica del \\ Noroeste de África $\left(22^{\circ} 30^{\prime} \mathrm{N}-26^{\circ} \mathrm{N}\right)$

\section{Hinde Abdelouahab ${ }^{1 *}$, Amina Berraho' ${ }^{2}$, Azeddine Ramzi ${ }^{2}$, Omar Ettahiri ${ }^{2}$, Ahmed Errhif ${ }^{1 * *}$ and Naoki Tojo ${ }^{3}$}

\begin{abstract}
'University Hassan II, Faculty of Sciences Ain Chock, B.P 5366 Maarif 20000, Casablanca, Morocco. *Corresponding author: hind.abdelouahab@gmail.com; **aerrhif@gmail.com

${ }^{2}$ National Institute of Marine Research, 2 Sidi Abderrahmane, Casablanca, Morocco. aminaberraho@gmail.com, omarettahiriomar@gmail.com, azeddine.ramzi@gmail.com

${ }_{3}^{3}$ Japan International Cooperation Agency (JICA), Expert of Resource Dynamics Analyses and Monitoring, National Institute of Marine Research, Casablanca, Morocco. bering.raven@gmail.com

Resumen.- El objetivo de este estudio fue estimar la mortalidad natural en los estados embrionarios y larvales de la sardina europea Sardina pilchardus a largo de la Costa Atlántica del Noroeste de África entre el Cabo Barbas $\left(22^{\circ} 30^{\prime} \mathrm{N}\right)$ y el Cabo Bojador $\left(26^{\circ} \mathrm{N}\right)$ durante noviembre de 2007. Se utilizaron datos planctónicos seleccionados de un estudio realizado en noviembre 2007 y ajustados a un modelo exponencial; el índice de mortalidad de huevos de sardina (Z) fue estimado en 0,07 (por hora), siendo el índice de mortalidad diario del $83,5 \%$. Por otra parte, para larvas de sardina, Z fue estimada en 0,1 (por hora), correspondiente a un índice de mortalidad diario igual al 21,4\%. Migraciones hacia el sur y costa afuera pueden ser consideradas como una causa de la variabilidad en la deriva y condiciones de sobrevivencia de larvas de sardina. Análisis adicionales de serie de tiempo de las primeras etapas del ciclo vital de las sardinas y la futura supervisión con programas de monitoreo adaptativo deberían ser conducidos para un mejor manejo de la industria pesquera de esta especie en Marruecos.
\end{abstract}

Palabras clave: Sardina, huevos, larvas, mortalidad, Noroeste África

\begin{abstract}
The purpose of this study was to estimate the natural mortality of embryonic and larval stages of European pilchard Sardina pilchardus along the Atlantic Coast of Northwest Africa between Cape Barbas $\left(22^{\circ} 30^{\prime} \mathrm{N}\right)$ and Cape Bojador $\left(26^{\circ} \mathrm{N}\right)$ during November 2007. Using planktonic data that were fitted to an exponential model, sardine eggs hourly mortality rate (Z) was estimated in 0.07 (per hour) corresponding to $83.5 \%$ of daily mortality rate. On the other hand, for sardine larvae, $Z$ was estimated in 0.01 (per hour), corresponding to a daily mortality rate of $21.4 \%$. Southward and offshore transport can be considered as causes of variability in drifting scenario and survival condition of sardine larvae. Additional analyses of time series of the early life history data of sardines and future adaptive monitoring should be conducted to better manage sardine fisheries in Morocco.
\end{abstract}

Key words: Sardine, eggs, larvae, mortality, Northwest Africa

\section{INTRODUCTION}

European pilchard, Sardina pilchardus (Walbaum, 1792) is one of the most important and abundant forage fishes along the northwest African Atlantic coast. In the regional ecosystem, it plays a key role in the trophic web as the dominant forage fish. Major S. pilchardus distribution in the northwestern African coast extends from Cape Blanc $\left(21^{\circ} \mathrm{N}\right)$ to Cape Spartel $\left(32^{\circ} \mathrm{N}\right)$ (Kifani \& Gohin 1992, Berraho 2007, Ettahiri et al. 2012). It is also one of the important fishing targets in this coastal area. In Morocco, small pelagic fishes represent more than $75 \%$ of total landings dominated by S. pilchardus (INRH 2002).
In northwest Africa, S. pilchardus spawning occurs throughout the year, although seasonal peaks of spawning depend on time and location (Berraho 2007). In the coastal area off Northwest Africa, spawning peaks were found in winter/ early spring between Cape Ghir $\left(31^{\circ} \mathrm{N}\right)$ and Cape Bojador $\left(26^{\circ} \mathrm{N}\right)$. Between Cape Bojador $\left(26^{\circ} \mathrm{N}\right)$ and Cape Blanc $\left(21^{\circ} \mathrm{N}\right)$, the principal spawning peaks were generally found in winter (mainly between November and December) at the northern part of Cintra Bay corresponding to temperatures ranging from 16.5 to $17.5^{\circ} \mathrm{C}$. In general, the temperature ranges 
between 15.5 and $17.5^{\circ} \mathrm{C}$ were suggested as the preferable thermal range of spawning for sardine (Berraho 2007). These temperature ranges are lower than the known thermal range of spawning windows for some species in similar ecological niches. For example, spawning peak of Sardinops sagax occurs at water temperatures between $18^{\circ} \mathrm{C}$ and $22^{\circ} \mathrm{C}$ in southern Queensland (Staunton-Smith \& Ward 2000).

Most pelagic forage fishes over the world like sardines are known to have large biomass fluctuations. In response to the environmental variability, S. pilchardus population in the Atlantic Ocean of South African coast and Namibia collapsed during 1965-1966 (Crawford \& Shannon 1988). Sudden population collapse of Japanese sardine (Sardinops melanostictus) in the early 1990's was most likely the result of the unsuccessful recruitment (Suda \& Kishida 2003, Watanabe 2009). The variability of recruitment success has been explained from the survival during the critical pre-recruitment phase (Hjort 1914, 1926). In the match/mismatch hypothesis by Cushing (1975), recruitment success depends on the timing of fish spawning and prey production. Ocean dynamics may influence the embryonic and larval survival and growth. Lasker (1981) proposed that in upwelling ecosystems the more stable ocean conditions are, the better survival and growth of larval fish are.

S. pilchardus stock of Morocco also experienced dramatic changes in abundance, especially in the 1997/1998, period that was characterized by a warming due to El Niño phenomena (INRH 2002). The population dynamics may have been impacted by the change in the early-life survival condition associated to the regional oceanography (INRH 2002). In the southern area of the northwestern Atlantic coast of Africa (21$26^{\circ} \mathrm{N}$ ), the upwelling activity provides a considerable supply of nutrients sustaining primary and secondary production in the ecosystems (Somoue et al. 2013, Demarcq \& Somoue 2015). Upwelled waters lower the Sea Surface Temperature (SST) and develop spatial heterogeneity in this area according to the variability of the upwelling center location and its intensity (Benazzouz et al. 2014). Many research activities have focused on physical and biological oceanography in this area, specifically spatio-temporal dynamics of the marine environment in relation to the upwelling. However, there have not been sufficient discussions in the population dynamics of S. pilchardus and observed oceanographic dynamics in this region in relation to the early life survival.

Houde (1987) suggested that mortality is critical during the early larval stages of a fish. Hjort's hypotheses constituted the background for the recent recruitment studies, mainly focused on the Critical Period hypothesis (Houde 2008). Fish recruitment success is associated to species/populations and environmental factors (Houde 2008, Garrido et al. 2015). The high mortality occurring at early life stages of fish is selective (Houde \& Schekter 1980), usually influenced by individual's phenotype (Johnson et al. 2014), and during larvae stage the mortality is highly size-dependent (Anderson 1988). Various studies have suggested that lower growth rates during larval phase results in higher mortality (Wilson \& Meekan 2002). The 'growth-mortality' hypotheses (Anderson 1988) have been usually used to explain the recruitment variation of marine fish populations. According to these hypotheses, faster growing individuals have a higher probability of survival. Fast growing larvae develop a strong swimming abilities comparing to small larvae, and experience a shorter stage-duration increasing their chance to survive and become less vulnerable to predation. Garrido et al. (2015) have concluded that survival probability of European pilchard $S$. pilchardus larvae is linked to the larval size at hatch. Therefore, prey availability probably influence dynamics of early life stages of fish and the limited feeding availability may be regulating year class success (Houde \& Schekter 1980). Nevertheless, mortality during this critical period can be influenced by several factors such as temperature (Blaxter 1992), physical processes (Cushing 1975), nutritional conditions, growth rates (Vigliola \& Meekan, 2002), etc.

Thus, mortality during the early life stages becomes an important research line for an adaptive monitoring and sustainable management of the European pilchard stock of Morocco. In this work, we aimed to discuss the early life survival of $S$. pilchardus in relation to the environmental conditions especially in the passive phase with estimation of the mortality in northwestern Atlantic coast of Africa between $22^{\circ} 30^{\prime} \mathrm{N}$ and $26^{\circ} \mathrm{N}$.

\section{Materials AND Methods}

\section{STUdy AREA AND SURVeys}

This study is based on data of a survey carried on board of the $\mathrm{R} / \mathrm{V}$ Al Amir Moulay Abdellah in the south zone of the African Atlantic coast between Cape Bojador $\left(26^{\circ} \mathrm{N}\right)$ and Cape Blanc $\left(21^{\circ} \mathrm{N}\right)$, in autumn 2007 , from November $21^{\text {st }}$ to December $2^{\text {nd }}$ (Fig. 1). A total of 40 stations were sampled extending over 12 transects, at a rate of 3 to 4 stations per transect. Eggs and larvae were collected using a Bongo net $(20 \times 20 \mathrm{~cm}$ mouth diameter, $300 \mu \mathrm{m}$ mesh size) by oblique tows ( $3 \mathrm{~min}$ ) with 2.5 knots. The Bongo net was equipped with flowmeters to estimate the volume of filtered water. Samples were immediately preserved in $5 \%$ borax buffered formalin solution in filtered sea water. 
Figure 1. Surveyed area curried out in November 2007, along the Atlantic Coast of Northwest Africa $\left(22^{\circ} 30^{\prime} \mathrm{N}-26^{\circ} \mathrm{N}\right)$. Cross circles indicate oceanographic sampling stations / Área de prospección realizada en noviembre 2007 a lo largo de la costa Atlántica del Noroeste de África $\left(22^{\circ} 30^{\prime} \mathrm{N}-26^{\circ} \mathrm{N}\right)$. Las cruces corresponden a las estaciones de muestreo oceanográficos

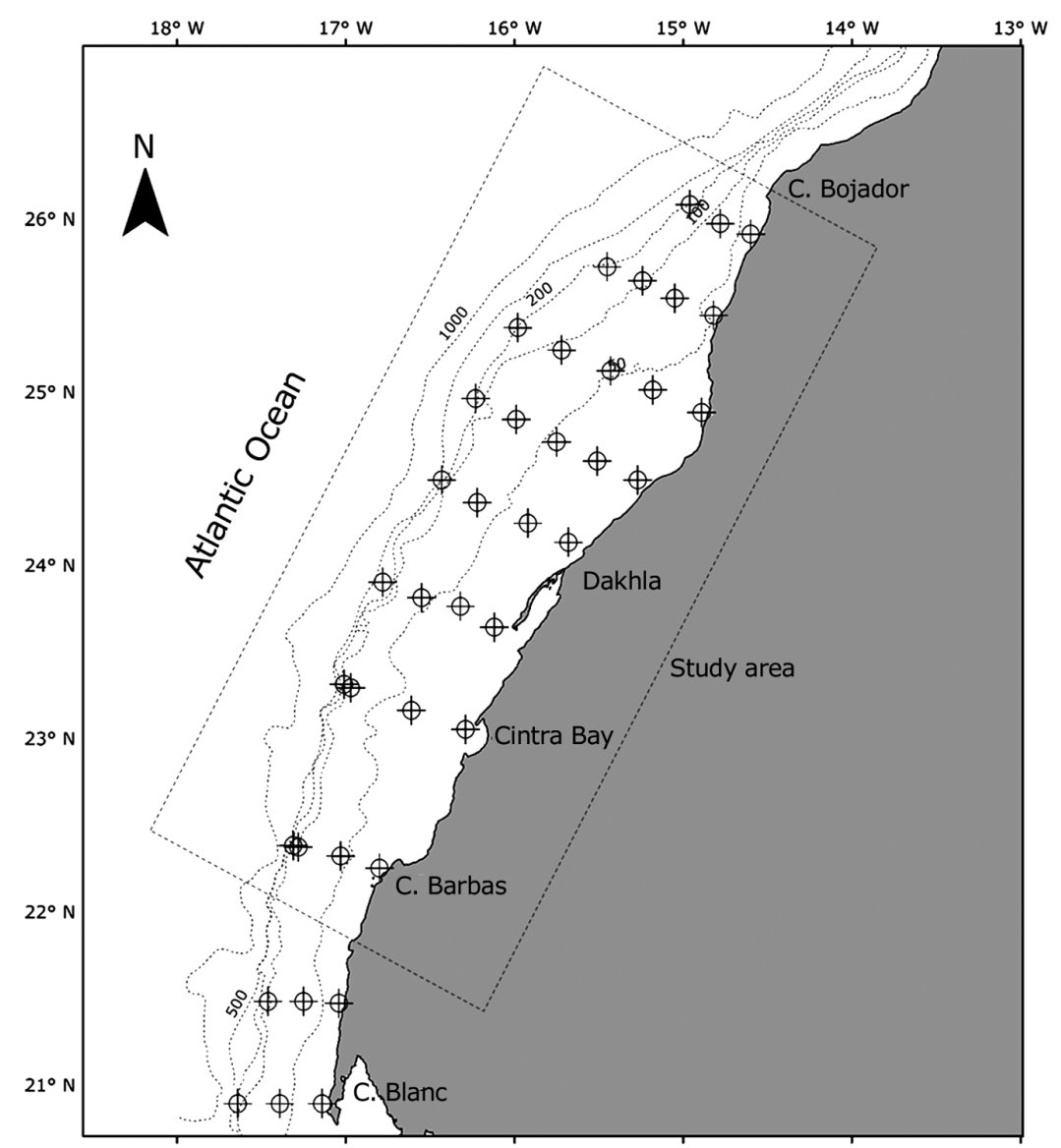

Sea surface temperature was measured using a CTD (Seabird SBE-911+) and water samples were collected by Niskin bottles to estimate chlorophyll $a$ concentration.

At the laboratory, all sardine eggs and larvae were sorted from the rest of plankton in samples and counted. Sardine eggs were classified into 11 embryonic stages according to the growth criteria (Ahlstrom 1943) while sardine larvae were measured and classified into $1 \mathrm{~mm}$ standard length classes. The abundance of sardine eggs and larvae was expressed into number per 10 $\mathrm{m}^{2}$ (Smith \& Richardson 1979).

Due to the weak abundance of eggs and larvae found in the two last transects at $21^{\circ} \mathrm{N}$ and $21^{\circ} 30^{\prime} \mathrm{N}$, the study area was limited to the main spawning zone located between $22^{\circ} 30^{\prime} \mathrm{N}$ $26^{\circ} \mathrm{N}$, composed of 33 stations to avoid bias in mortality rates estimation.

\section{Spatial distribution of Biological and ENVIRONMENTAL CONDITIONS}

Spatial distribution maps of eggs and small larvae (sized less than $7 \mathrm{~mm}$ ) are presented separately in 3 maps: eggs, newly hatched eggs (larvae aged < 4 days) and larvae aged between 4 and 7 days. Here the threshold size of $7 \mathrm{~mm}$ corresponds to the dorsal fin apparition and is considered as a limit between small and large larvae (Berraho et al. 2012). Kernel density estimation (KDE) was used to show spatial distribution of both eggs and larvae. They were also statistically examined to pinpoint eggs and larvae distribution using geostatistical analysis.

Related environmental conditions including sea surface temperature and chlorophyll $a$ maps are showed. Average temperature between surface and $10 \mathrm{~m}$ map distribution was obtained by ordinary kriging and chlorophyll $a$ interpolation was performed by probability kriging after normalization. 


\section{ESTIMATION OF THE MORTALITY}

Estimation of the mortality was done in 2 major steps. First step was devoted to age estimation of eggs and larvae. Then, embryonic and larval mortality rates of $S$. pilchardus were estimated by applying an exponential decay model (eq. 3).

For sardine eggs age estimation, the model established by Lo (1985) was used and adjusted as in Ettahiri (1996):

$$
\mathrm{Y}_{\text {egg }}=10.73 \times \mathrm{e}^{(-0.1612 \mathrm{i}-0.0924 \times \mathrm{T})} \mathrm{X} \mathrm{i}^{1.955}
$$

where

$Y$ : age of eggs per hour

$i$ : embryonic stages $(i=1,2, \ldots 11)$

$T$ : temperature $\left({ }^{\circ} \mathrm{C}\right)$

For larvae age estimation, the relationship between size and age was considered. The larvae growth rate considered for the Moroccan S. pilchardus was $0.6 \mathrm{~mm}^{\text {day }}{ }^{-1}$ (Ettahiri 1996). Larvae sorted from samples were measured and grouped by size class of $1 \mathrm{~mm}$. In the analysis, we focused on small larvae $(<7 \mathrm{~mm})$ because large larvae $(>7 \mathrm{~mm})$ develop stronger swimming capabilities and present a high net avoidance which can bias the mortality rate estimation.

The estimation of larvae age $\left(\mathrm{Y}_{\text {larv }}\right)$ is obtained from the following formula:

$$
\mathrm{Y}_{\text {larv }}=\left(\mathrm{L}_{\mathrm{obs}}-\mathrm{L}_{0}\right) / \mathrm{G}
$$

$L_{0}$ : Standard length of newly hatched larvae approximately equals $2.5 \mathrm{~mm}$

$L_{o b s}:$ observed length of larvae (in $\mathrm{mm}$ )

$G$ : Growth rate of Sardine larvae $\left(0.6 \mathrm{~mm} \mathrm{day}^{-1}\right)$

\section{EXPONENTIAL DECAY MODEL}

Mortality estimation of egg and larvae of S. pilchardus was calculated using an exponential decay model:

$$
\mathrm{N}_{\mathrm{t}}=\mathrm{N}_{0} \times \mathrm{e}^{-\mathrm{Zt}}
$$

$N_{t}:$ Egg/Larvae density at time $t$ (ind. per $10 \mathrm{~m}^{2}$ )

$N_{0}:$ Egg/Larvae density at time $t=0$

$Z$ : Instantaneous mortality rate (per hour)

$t$ : Time (hours)

\section{Model FITTING}

Assuming that the spawning patterns are the same during the sampling period and that the emigration/immigration in the area is balanced, using a natural-log transformation of equation (3), we obtain the linear equation:

$$
\mathrm{LN}\left(\mathrm{N}_{\mathrm{t}}\right)=\mathrm{LN}\left(\mathrm{N}_{0}\right)-\mathrm{Zt}
$$

Then, parameters $N_{0}$ and $Z$ can be estimated using a linear regression of the above equation as following:

$$
\mathrm{N}_{0}=\exp (\text { intercept }) ; \mathrm{Z}=- \text { Coeff }
$$

where intercept and Coeff are the parameters of the linear regression of equation (4).

Based on the equation (3), daily percentage of death of egg or larvae (\%D) can be estimated by applying the equation (5):

$$
\% \mathrm{D}=100 \times\left(1-\mathrm{e}^{-\mathrm{zt}}\right)
$$

where $t=24$ hours

All statistical analyses were carried out using R 2.15.2 (R Core Team).

\section{Results}

\section{REVIEW OF THE ENVIRONMENTAL CONDITIONS DURING 2007}

Distribution of average sea surface temperature showed a differentiation of two coastal patterns of low temperature near to the coast. First one was observed between Cape Bojador and north of Dakhla $\left(24^{\circ} 30^{\prime} \mathrm{N}\right)$, while the second one was located in the south of Cape Barbas. Differences in water temperature were around $1.3^{\circ} \mathrm{C}$. Relatively high temperatures were observed in the north part especially in the offshore and low temperature in the southern part of the study area. Chlorophyll $a$ probability of occurrence was higher in the southern part of the study area than in the northern part (almost two times higher). The spatial distribution of the interpolated surface temperature (Fig. 2a) suggests an inshore-offshore and north-south gradient. Temperatures less than $19^{\circ} \mathrm{C}$ in the south part, probably due to the presence of an upwelling activity, were observed between Cape Barbas and Cape Blanc area and between Cape Bojador and Dakhla.

The surface concentrations of chlorophyll $a$ in the study area reached $4.68 \mu \mathrm{g} \mathrm{L}^{-1}$. Mean concentration recorded was about $0.6 \mu \mathrm{g} \mathrm{L}^{-1}$ and high concentrations were recorded south of Cape Barbas (Fig. 2b).

\section{EgGS AND LARVAE SARDINE DISTRIBUTION}

Sardine eggs showed a heterogeneous spatial distribution along the study area where high abundance recorded essentially between $23^{\circ} \mathrm{N}$ and $25^{\circ} \mathrm{N}$ with a maximum of 48,884 ind $10 \mathrm{~m}^{-2}$ (off Dakhla). 




Figure 2. Distribution maps of a) average temperature and b) probability of presence of chlorophyll a. Interpolated of average temperature $\left({ }^{\circ} \mathrm{C}\right)$ was from surface to $10 \mathrm{~m}$. Probability of occurrence of sea surface chlorophyll a / Mapas de distribución de a) temperatura media y b) probabilidad de presencia de clorofila a. Interpolación de la temperatura media $\left({ }^{\circ} \mathrm{C}\right)$ desde la superficie hasta $10 \mathrm{~m}$ de profundidad. Probabilidad de ocurrencia de la concentración de clorofila a en la superficie del mar

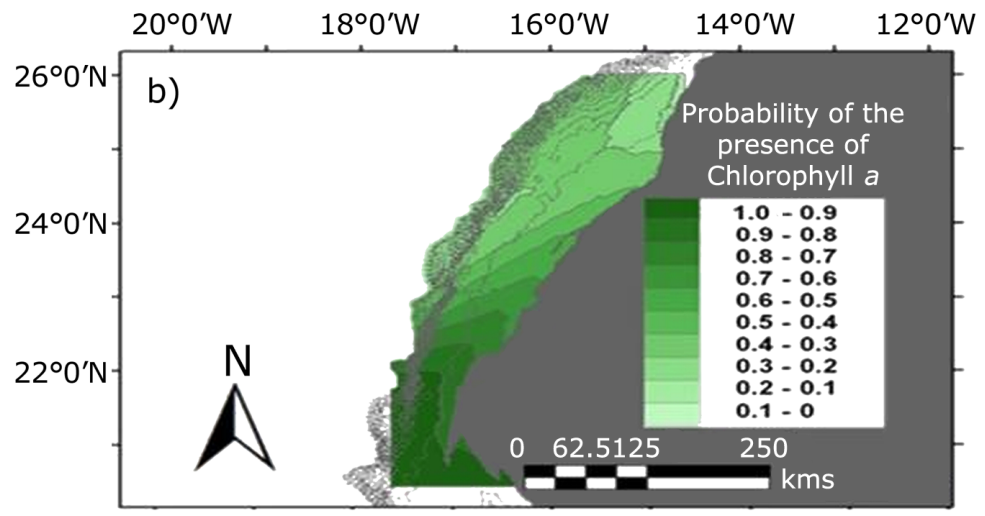

\begin{abstract}
Table 1. Estimation of the parameters $Z$ (instantaneous mortality rate) and $\mathrm{N}_{0}$ (density at time $\mathbf{t}=\mathbf{0}$ ) for eggs of Sardina pilchardus / Estimación de los parámetros Z (tasa instantánea de mortalidad) y $N_{0}$ (densidad en el tiempo $t=0$ ) para los huevos de Sardina pilchardus
\end{abstract}

\begin{tabular}{lcccc}
\hline & Estimate & $\begin{array}{c}\text { Standard } \\
\text { error }\end{array}$ & $P$-value $(>|\mathrm{t}|)$ & \\
\hline Intercept & 7.45 & 0.83 & $4.20 \mathrm{E}-09$ & $* * *$ \\
Coeff & -0.07 & 0.03 & 0.04 & $*$ \\
\hline
\end{tabular}

$\mathrm{R}^{2}=0.16 ; P$-value: 0.04 ( $P$-value $<0.05$, significant $) ; \mathrm{N}_{0}=1719.86$; $\mathrm{Z}=0.07$

After hatching, the spatial distribution of larvae aged less than 4 days showed a clustered distribution over the study area. Highest abundances were observed in the north and south of the study area.

Larvae older than 4 days were distributed mainly in offshore suggesting a southward/offshore displacement. Relatively high density (> 3rd quartile) was still observed in the extreme south part (Fig. 3).

Looking at the semivariograms, the relative density of sardine for eggs and larvae aged less than 4 days, still show spatial correlations up to some thresholds and the semivariograms can be fitted to a theoretical model. But, this spatial pattern was lost for the > 4-days age phase and could not be well fitted, which means that there is no clear spatial correlations for the observed densities (Fig. 4).

\section{EMBRYONIC MORTALITY OF SARDINE}

The mortality rate of eggs $(Z)$ was estimated to 0.075 (per hour) corresponding toa daily mortality rate approximately equal to $83.5 \%$ (Table 1). $N_{0}$ was estimated to 1720 eggs per $10 \mathrm{~m}^{2}$. In some stations, abundance of eggs was extremely high and the sensitivity to those extreme values was taken into consideration by applying the CI (95\%) (Fig. 5) 
Figure 3. Distribution map of the passive phase of early-life stage of Sardina pilchardus. a) Eggs; b) Larvae aged less than 4-days; c) Larvae aged greater than 4-days). Size of circles indicates the abundance in statistical quantiles, and cross marks are where no eggs or larvae were captured. Contours are based on best-fit probability kriging / Mapa de distribución de la fase pasiva en los primeros estadios de desarrollo de Sardina pilchardus. a) Huevos; b) Larvas con menos de 4 días; c) Larvas mayores de 4 días. El tamaño de círculos indica la densidad relativa en cuantiles estadísticos, y la cruz indica donde no hubo huevos o larvas capturadas. Los contornos están basados en la probabilidad mejor adaptada al método kriging

Figure 4. Semivariograms of the transformed density of passive phase of early-life stage of Sardina pilchardus a) Egg; b) <4-day age larvae; c) >4-day age larvae, over the study area. Densities were transformed into normal scores between 0 and 1 before the calculation of the semivariograms. Black dots are the empirical semivariograms. Lines are the best-fit spherical semivariogram models / Semivariogramas de la densidad transformada de la fase pasiva en los primeros estadios de desarrollo de Sardina pilchardus. a) Huevo; b) edad de larvas < 4 días; c) edad de larvas > de 4 días en el área del estudio. La densidad fue transformada en puntuación normal entre 0 y 1 antes del cálculo del semivariograma. Puntos negros son semivariogramas empíricos. Las líneas son modelos de semivariogramas esféricos que mejor se adaptan
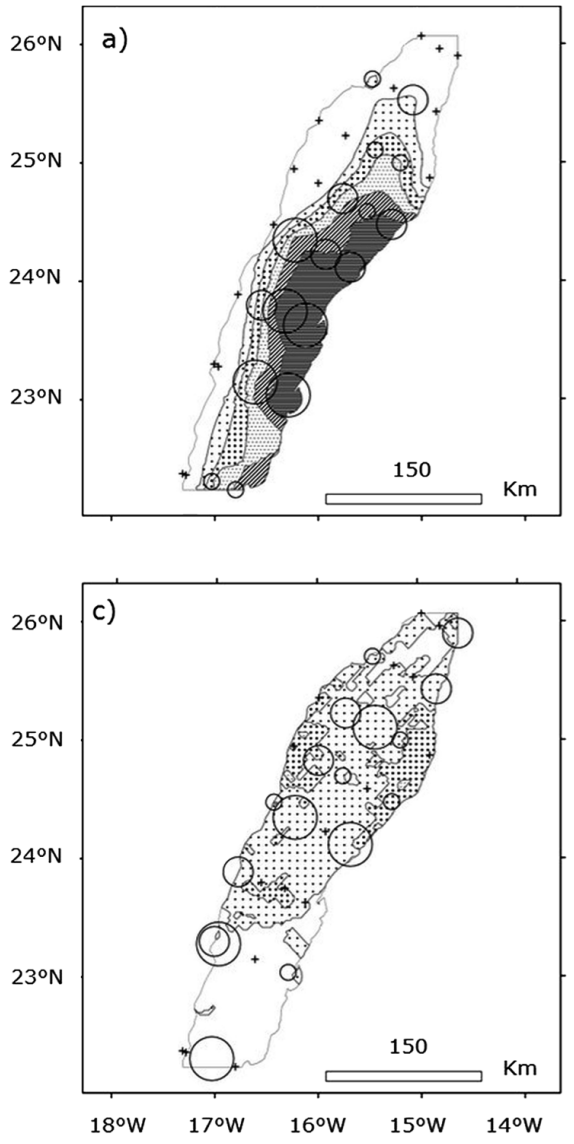

Statistical quantile and zero
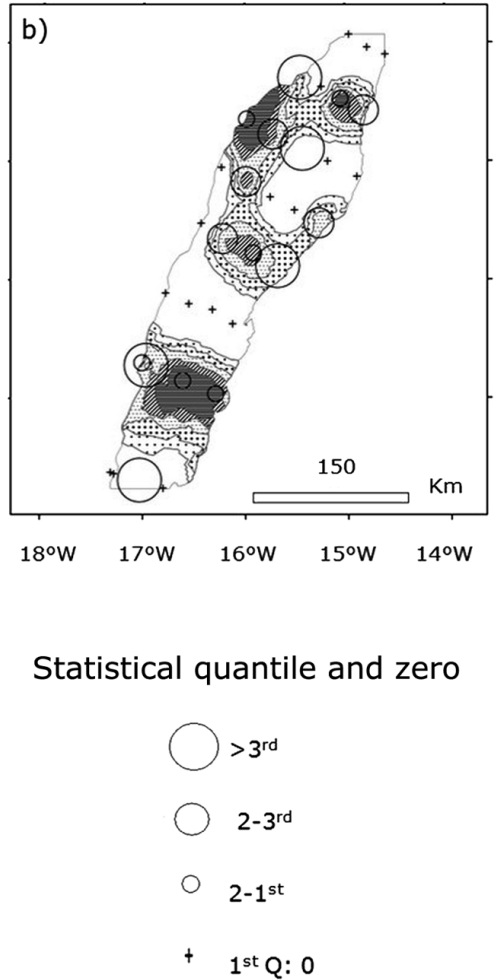

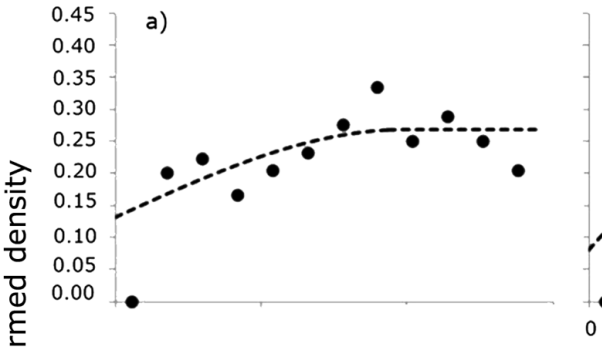

b)

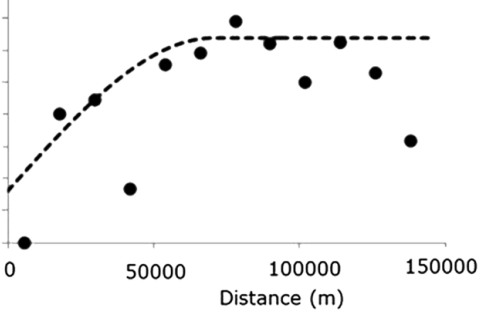
$\bullet$

$+0.35$

앙 0.30

0.25

0.25
0.20
0.15

0.10

0.05

0.00

0
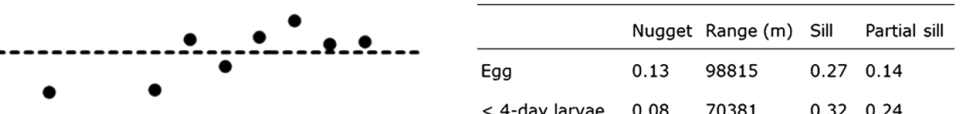

$\begin{array}{llllll}<\text { 4-day larvae } & 0.08 & 70381 & 0.32 & 0.24\end{array}$

$>$ 4-day larvae $0.26 \quad \ldots \quad \ldots$ 

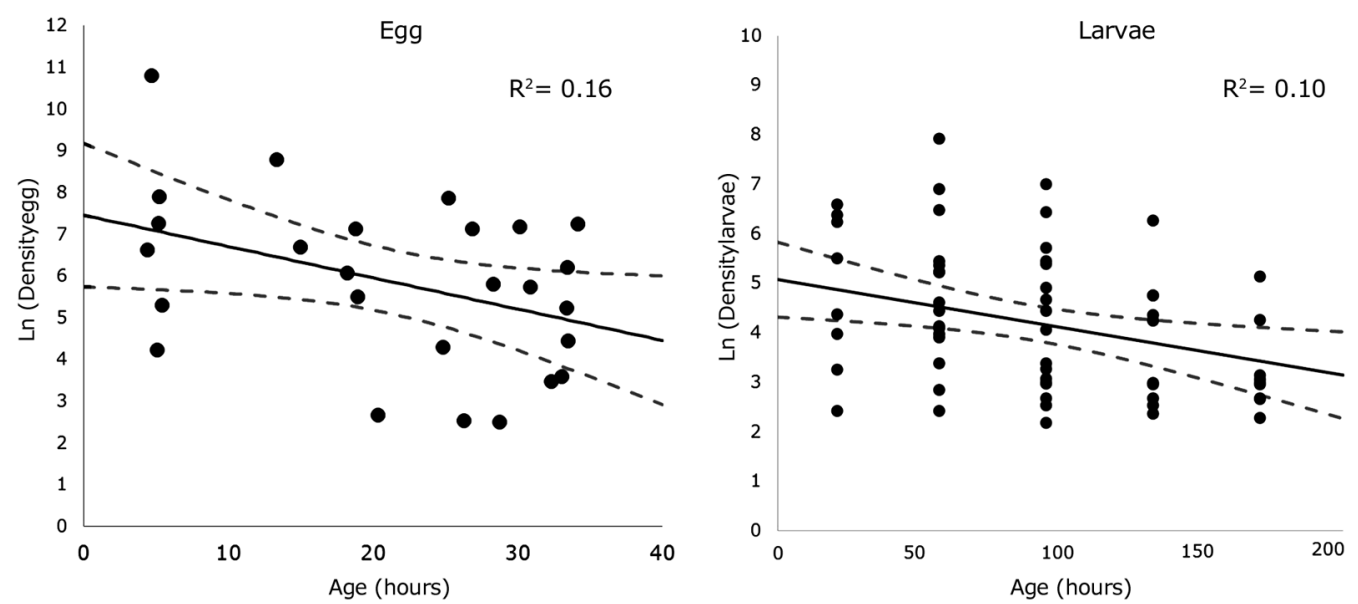

Figure 5. Representation of the linear regression model with natural-log transformed egg or larvae density relation to the age (hours). Black dots are the natural-log transformed egg or larvae density. Black lines are linear regression. Dotted lines are the upper and lower limit of the Confidence Interval (95\%) / Representación del modelo de regresión lineal con el logaritmo natural truncado y transformado de la densidad de huevo o larvas en relación a la edad (horas). Puntos negros serian el logaritmo natural truncado transformado de la densidad de huevos o larvas. Líneas negras corresponden a la regresión lineal y líneas de puntos sería el límite superior e inferior del intervalo de confianza (95\%)

Table 2. Estimation of the parameters $Z$ (instantaneous mortality rate) and $N_{0}$ (density at time $\mathbf{t}=\mathbf{0}$ ) for larvae of Sardina pilchardus / Estimación de los parámetros $Z$ (tasa instantánea de mortalidad) y $N_{0}$ (densidad en el tiempo $t=0$ ) para larvas de Sardina pilchardus

\begin{tabular}{ccccc}
\hline & Estimate & $\begin{array}{c}\text { Standard } \\
\text { Error }\end{array}$ & $P$-value $(>|\mathrm{t}|)$ & \\
\hline Intercept & 5.07 & 0.37 & $<2 \mathrm{e}-16$ & $* * *$ \\
coeff & -0.01 & 0.003 & 0.01 & $*$ \\
\hline
\end{tabular}

$\mathrm{R}^{2}=0.10 ; P$-value: $0.011(P$-value $<0.05$, significant $) ; \mathrm{N}_{0}=159.17$ $\mathrm{Z}=0.01$

\section{LARVAL MORTALITY OF THE SARDINE}

The mortality rate $Z$ of sardine larvae in this study area was estimated to 0.01 (per hour) corresponding to a daily mortality rate of $21.4 \%$ and $N_{0}$ was estimated to 159 larvae per $10 \mathrm{~m}^{2}$ (Table2). A linear regression with natural-log transformed larvae density in relation to the age was established (Fig. 5).

\section{DiscuSSION}

Both embryonic and larval mortality of S. pilchardus in the southern area of the northwest African coast was estimated based on in situ samples collected in November 2007. The eggs were observed near the main spawning grounds located around Dakhla (Berraho 2007). This region is characterized by a large, flat and not deep continental shelf which constitutes a favorable place for retention of eggs and larvae and for their development (Ettahiri et al. 2012). The estimated embryonic mortality was comparable to the available past information in the area extending from $32^{\circ} \mathrm{N}$ to $26^{\circ} \mathrm{N}$ of Atlantic Moroccan coast for the same species estimated to $84 \%$ (Ettahiri 1996). The daily mortality of eggs of the kin species, Sardinops sagax, was $88 \%$ of dead eggs per day in the central part of the Peruvian waters and reached $98 \%$ in the northern region of Peru (Smith et al. 1989), while in the Pacific coast the egg mortality rate estimated for Sardinops caerulea was 36\% (Smith 1973). However, in the Japanese coast, characterized by the presence of other oceanographic features (other than upwelling), the daily egg mortality rate estimated for Sardinops melanostictus was 40\% (Tanaka 1974). Multiple causes influence the variability of the estimated daily embryonic mortality rate, including spatiotemporal changes of environmental conditions (temperature, physical processes, etc), species feeding behavior (predation, cannibalism) and even the sampling strategy. Larval mortality of $S$. pilchardus $(<7 \mathrm{~mm})$ was not as high as the embryonic mortality. It suggests higher vulnerability of $S$. pilchardus in egg phase than in larval phase. Either on-site thermal condition 
or ecological interactions such as predations upon eggs may have driven the higher mortality rate (Santander et al. 1983, Kucharczyk et al. 1997). The mortality experienced during larval stage is extensively due to the larvae size (Garrido et al. 2015) where smaller larvae are more vulnerable to predators than others. Therefore, negative size selection of prey by the potential predators is conditioned by the high presence prey of smaller size and decreasing number of predators when the prey size increases (Takasuka et al. 2003). Then, size-selective predation may cause high larvae mortality among other causes.

Optimum temperature with stability of water column enhance embryonic growth, and sufficient availability of prey is required for the successful survival of the larvae (Riveiro et al. 2000, Kucharczyk et al. 1997, Kujawa et al.1997). Thus, fairly consistent transport and associated successful retention of eggs and larvae over the large and productive coastal shelf in this area are probably advantageous for their growth and survival. The area around Dakhla $\left(24^{\circ} \mathrm{N}\right)$, where the majority of eggs were observed, is characterized by a large and flat continental shelf, limiting the dispersal toward the offshore (Roy 1991). The observed extension of productive cold water along coast may have provided adequate environment for the larval growth. The observed southward extension of larval distribution is probably consequence of a passive drift associated to the southward surface current (Mittelstaedt 1991, Ettahiri et al. 2003).

In November 2007 SST showed gradients that may have affected the survival of sardine eggs and larvae. Faster growth of egg and larvae will be enhanced by warmer temperature in the observed range of the temperature though effect of direct thermal shock and associated infections is uncertain (Lo 1985, Miranda et al. 1990). Especially for eggs, the spread surface water with temperature higher than $20^{\circ} \mathrm{C}$ would have accelerated the growth in the study area in November 2007. On the other hand, the productive southern water extended along the coastline in the area may be advantageous to the survival of larvae (Varela 1992).

As the discussion in the 'Optimal Environment Window' hypothesis (Cury \& Roy 1989) and 'Stable Ocean' (Lasker 1981), nutrient inputs from upwelling and stability of water column over the coastal shelf of the study area provide high production of primary producers and optimum habitat conditions for the survival of early life $S$. pilchardus. Depending upon the balance of the southern productive water and $>20^{\circ} \mathrm{C}$ surface water in the study area, survival scenario of the $S$. pilchardus must be seasonally and inter-annually different.

Egg and larval mortalities in this area may be due to the physical structure in addition to the spatial thermal conditions and food availability. The variability of the mortality rate and the hatching timing will be depending upon the extension of cold and nutrient rich water from the upwelling in the area. Since we have only single survey information, the specific range of the variability in the mortality rate and the hatching timing needs further data and studies. The mortality in 2007 was comparable to the other years in this region in early 1990s' (Ettahiri 1996).

Upwelling in the region including the study area in autumnwinter is not extremely intense (Benazzouz et al. 2014) though the intensity is interannually variable. In 2007, relatively high autumn-winter upwelling in the northern area from $24^{\circ} \mathrm{N}$, resulted in the along-coast extension of the cold and productive water. In this extension, nearshore eggs may have taken time for embryonic growth comparing to the area $>50 \mathrm{~m}$ bottom depth. Though the high primary production may be beneficial for the larvae, it will be significant after the beginning of the active feeding. Thus, offshore transports after observed early larval phase will be the key of the early-life survival. The growth rate and retention success in the given environmental conditions probably played the keys of the early-life survival in this region, which can be confirmed by more investigations using times series of eggs, larvae and environmental data. Furthermore, variability in upwelling seems to be the major driver of the survival condition. Though the thermal condition derived from upwelling may be preferable for spawning (Berraho et al. 2005), the condition might have been disadvantageous for retention, growth and survival of passive phase of $S$. pilchardus.

To examine the hypothesized scenario, further analysis using time series is necessary. Improving the sampling design to study the mortality of pre-recruitment stages will allow future research to test previous assumptions and follow the dynamics of fish population taking into account the transport effect. Considering the importance of quantitative information in the pre-recruitment survival and recruitment success in the resource management, oceanographic monitoring to confirm presented mortality dynamics hypothesis will be essential to establish the sustainable S. pilchardus resource assessment and fisheries.

\section{ACKNOWLEDGMENTS}

The authors thank the entire scientific team involved in sampling on board the research vessel Al Amir Moulay Abdellah and the Moroccan-Japanese coordinators and scientific team who contributed in the present work.

\section{LITERATURE CITED}

Ahlstrom EH. 1943. Studies on the pacific pilchard or sardine (Sardinops coerulea). In: Influence of the temperature on the rate of development of pilchards eggs in nature. U.S. Fish and Wildlife Service: Fishery Bulletin 23: 1-26. 
Anderson JT. 1988. A review of size dependent survival during prerecruit stages of fishes in relation to recruitment. Journal of Northwest Atlantic Fishery Science 8: 55-66.

Benazzouz A, S Mordane, A Orbi, M Chagdali, K Hilmi, A Atillah, JL Pelegrí \& H Demarcq. 2014. An improved coastal upwelling index from sea surface temperature using satellite-based approach - The case of the Canary Current upwelling system. Continental Shelf Research 81:38-54.

Berraho A. 2007. Relation spatialisée entre milieu et ichtyoplancton des petites pélagiques de la côte Atlantique marocaine (zones centrale et sud). Thesis Doctoral, Mohammed V Agdal University, Rabat, 261 pp.

Berraho A, O Ettahiri, Y Letourneur, A Orbi \& A Yahyaoui. 2005. Importance des paramètres hydrologiques dans la distribution des œufs et larves des petits pélagiques du sud de l'Atlantique marocain. Cybium 29(1): 21-31.

Berraho A, O Ettahiri, T Brochier, A Benazzouz, J Larissi, A Makaoui, L Somoue, S Salah, K Hilmi \& A Orbi. 2012. Distribution des larves de sardine et d' anchois le long du filament du Cap Ghir (région nord-ouest Africaine). Journal des Sciences Halieutique et Aquatique 6: 178-193.

Blaxter JHS. 1992. The effect of temperature on larval fishes. Netherlands Journal of Zoology 42(2): 336-357.

Crawford RJM \& LV Shannon. 1988. Long term changes in distributions of fish catches in the Benguela. In: Wyatt T \& MG Larrañeta (eds). Long term changes in marine fish populations, pp. 449-480. Consejo Superior de Investigaciones Científicas, Vigo.

Cury P \& C Roy. 1989. Optimal environmental window and pelagic fish recruitment success in upwelling areas. Canadian Journal of Fisheries and Aquatic Sciences 46(4): 670-680.

Cushing DH. 1975. Marine ecology and fisheries, 278 pp. Cambridge University Press, Cambridge.

Demarcq H \& L Somoue. 2015. Phytoplankton and primary productivity off northwest Africa. In: Valdés L \& I DénizGonzález (eds). Oceanographic and biological features in the Canary Current Large Marine Ecosystem, pp. 161-174. IOC-UNESCO, IOC Technical Series, Paris.

Ettahiri O. 1996. Etude de la phase planctonique de la sardine, Sardina pilchardus (Walb.), et de l'anchois, Engraulis encrasicolus (L.) des côtes atlantiques marocaines Thesis Doctoral, University of Western Brittany, Brest, 252 pp.

Ettahiri O, A Berraho, G Vidy, M Ramdani \& T Do Chi. 2003. Observation on the spawning of Sardina and Sardinella off the south Moroccan Atlantic coast $\left(21-26^{\circ} \mathrm{N}\right)$. Fisheries Research 60(2): 207-222.

Ettahiri O, A Berraho, R Houssa, A Ramzi, L Somoue, S Zizah \& E Machu. 2012. Characteristics of the spawning habitats of sardine, Sardina pilchardus, off the Moroccan Atlantic coast $\left(21^{\circ} \mathrm{N}-26^{\circ} \mathrm{N}\right)$. FAO, Comptes Rendues des Pêches et de l'Aquaculture 18: 157-186.
Garrido S, R Ben-Hamadou, AMP Santos, S Ferreira, MA Teodósio, U Cotano, X Irigoien, MA Peck, E Saiz \& P Ré. 2015. Born small, die young: Intrinsic, size-selective mortality in marine larval fish. Nature Scientific Reports 5: 17065 < doi: $10.1038 /$ srep17065>

Hjort J. 1914. Fluctuations in the great fisheries of Northern Europe. Rapports et Procès-Verbaux des Réunions / Conseil Permanent International pour l'Exploration de la Mer 20: 1228

Hjort J. 1926. Fluctuations in year classes of important food fishes. Journal Conseil Permanent International pour l'Exploration de la Mer 1(1): 5-38.

Houde ED. 1987. Fish early life dynamics and recruitment variability. American Fisheries Society Symposium 2: 17-29.

Houde ED. 2008. Emerging from Hjort's Shadow. Journal of the Northwest Atlantic Fishery Science 41: 53-70.

Houde ED \& RC Schekter. 1980. Feeding by marine fish larvae: developmental and functional responses. Environmental Biology of Fishes 5(4): 315-334.

INRH. 2002. Les ressources halieutiques marocaines: situation et niveaux d'exploitation, $167 \mathrm{pp}$. Document Technique, Institut National de Recherche Halieutique, Casablanca.

Johnson DW, K Grorud-Colvert, S Sponaugle \& BX Semmens. 2014. Semmens1 Phenotypic variation and selective mortality as major drivers of recruitment variability. Ecology Letters 17: 743-755.

Kifani S \& F Gohin. 1991. Dynamique de l'upwelling et variabilité spatio-temporelle de la répartition de la sardine marocaine, S. pilchardus (Walbaum, 1972). Oceanologica Acta. 15(2): 173-186.

Kucharczyk D, M Luczynski, R Kujawa \& P Czerkies. 1997. Effect of temperature on embryonic and larval development of bream (Abramis brama L.). Aquatic Science 59(3): 214-224

Kujawa R, A Mamcarz \& D Kucharczyk. 1997. Effect of temperature on embryonic development of asp (Aspius aspius L). Polskie Archiwum Hydrobiolgii 44(1-2): 139-143.

Lasker R. 1981. The role of a stable ocean in larval fish survival and subsequent recruitment. In: Lasker R (ed). Marine fish larvae morphology, ecology and relation to fisheries, pp. 8087. University of Washington Press, London.

Lo NCH. 1985. A model for temperature dependent northern anchovy egg development and an automated procedure for the assignment of age to staged eggs. In: Lasker R (ed). An egg production method for estimating spawning biomass of pelagic fish. Application to the northern anchovy, Engraulis mordax. NOAA Technical Report NMFS 36: 43-50.

Miranda A, R Cal \& J Iglesias. 1990. Effect of temperature on the development of eggs and larvae of sardine Sardina pilchardus Walbaum in captivity. Journal of Experimental Marine Biology and Ecology 140(1-2): 69-77. 
Mittelstaedt E. 1991. The ocean boundary along the Northwest African coast: circulation and oceanographic properties at the sea surface. Progress in Oceanography 26(4): 307-355.

Riveiro L, C Guisande, M Lloves, I Maneiro \& JM Cabanas. 2000. Importance of parental effects on larval survival in Sardina pilchardus. Marine Ecology Progress Series 205: 249-250.

Roy C. 1991. Les upwellings: le cadre physique des pêcheries côtières ouest-africaines. In: Cury P \& C Roy (eds). West African fisheries. Variability, instability and change, pp. 3866. Océanographie ORSTOM, Dakar.

Santander H, J Alheit, AD MacCall \& A Alamo. 1983. Egg mortality of the Peruvian anchovy (Engraulis ringens) caused by cannibalism and predation by sardines (Sardinops sagax). In: Sharp GD \& J Csirke (eds). Proceedings of the expert consultation to examine changes in abundance and species composition of neritic fish. FAO Fisheries Report 291(3): 444-453. FAO, Rome.

Smith PE. 1973. The mortality and dispersal of sardine eggs and larvae. Rapports et procès-verbaux des réunions / Conseil International de Conseil Permanent International Pour l'Exploration de la Mer 164: 282-292.

Smith PE \& SL Richardson. 1979. Técnicas modelo para prospecciones de huevos y larvas de peces pelágicos. FAO Documento Técnico de Pesca 175: 1-107.

Smith PE, H Santander \& J Alheit. 1989. Comparison of the mortality rates of Pacific Sardine, Sardinops sagax, and Peruvian anchovy, Engraulis ringens, eggs off Peru. U.S Fishery Bulletin 87: 497-508.

Somoue L, A Berraho, O Ettahiri, N Elkhiati, M Ramdani, J Larissi, A Makaoui \& HT Lam. 2013. Le plancton (phytoplancton, zooplancton et ichtyoplancton) de la côte Atlantique sud marocaine (Cap Boujdor-Cap Blanc). Travaux de l'Institut Scientifique, Rabat, Série Zoologie 49: 7-18.
Staunton-Smith J \& TM Ward. 2000. Stock assessment of pelagic bait fishes in southern Queensland with special reference to pilchards (Sardinops sagax). FRDC Projects 95/043: 1-126. Queensland Department of Primary Industries, Brisbane.

Suda M \& T Kishida. 2003. A spatial model of population dynamics of early life stages of Japanese sardine, Sardinops melanostictus, off the Pacific coast of Japan. Fisheries Oceanography 12(2): 85-99.

Takasuka A, I Aoki \& I Mitani. 2003. Evidence of growthselective predation on larval Japanese anchovy Engraulis japonicus in Sagami Bay. Marine Ecology Progress Series 252: 223-238.

Tanaka S. 1974. Significance of egg and larval surveys in the studies of population dynamics of fish. In: Blaxter JHS (ed). The early life history of fish, pp. 152-157. Heidelberg, Springer.

Varela F. 1992. Whence perceptual meaning? A cartography of current ideas. In: Varela F \& JP Dupuy (eds). Understanding origins: Contemporary views on the origins of life, mind and society, pp. 235-263. Kluwer Academic, Boston.

Vigliola L \& M Meekan. 2002. Size at hatching and planktonic growth determine post-settlement survivorship of a coral reef fish. Oecologia 131: 89-93.

Watanabe Y. 2009. Recruitment variability of small pelagic fish populations in the Kuroshio-Oyashio Transition Region of the Western North Pacific. Journal of Northwest Atlantic Fishery Science 41: 197-204.

Wilson DT \& MG Meekan. 2002. Growth-related advantages for survival to the point of replenishment in the coral reef fish Stegastes partitus (Pomacentridae). Marine Ecology Progress Series 231:247-260 